\title{
WELLNESS TOURISM IN UBUD. "A QUALITATIVE APPROACH TO STUDY THE ASPECTS OF WELLNESS TOURISM DEVELOPMENT"
}

\author{
Prilicia Meikassandra ${ }^{1}$, I Wayan Sukma Winarya Prabawa ${ }^{2}$, I Wayan Mertha ${ }^{3}$ \\ Undergraduate Student of Tourism Destination ${ }^{1}$, Associate Professor of Tourism \\ Department ${ }^{2,3}$ \\ Politeknik Pariwisata Bali \\ meikassandraprilicia@gmail.com
}

\begin{abstract}
This study aims to describe the aspects of wellness tourism development in Ubud. Adopted from Corbin theory (2006) which states the body, mind and spirit as part of the five dimensions of wellness, namely physical wellness, emotional wellness, social wellness, intellectual wellness, and spiritual wellness, authors would therefore to identify product wellness, wellness activities, wellness dimension and life cycle of development of wellness tourism in Ubud. This study uses qualitative research methods, starting with literature studies related research about wellness tourism and in-depth interviews with wellness service providers in Ubud. In this study, the authors reviewed the literatures and analyzed the information collected from eight wellness service providers. The eight informants are determined by considering the type of wellness service scale such as spa resorts, health resorts, retreat centers, and wellness centers, located in Ubud. The results showed that wellness tourism in Ubud had fulfilled aspects and dimensions of wellness. This is reflected from the identification which was resulted where the highest-demanded wellness products in Ubud, namely yoga retreats, meditation retreats, spiritual retreats, detoxes and spa resorts. While wellness activities in Ubud are considered more relevant to BalineseHinduism lifestyles such as customs, cultural-religion activities and valuable-local knowledge of Balinese herbs in which are part of the wellness experience offered in Ubud. While in the terms of phase of development, the current situation of wellness tourism stays in development phase.
\end{abstract}

Keywords: Wellness Tourism; Wellness Development; Tourism in Ubud

\section{INTRODUCTION}

Based on a study conducted by the Global Wellness Institute, the development of wellness tourism throughout the world has getting increased. In terms of expenditure, it grew from US \$ 563 billion in 2015 to US \$ 639 billion in 2017. Moreover, the number of trips it has also increased. In 2017 the number of wellness tourism trips reached 830 million trips, in contrast to 2015 which previously only had reached 691 million trips (Youngman, 2018). This statistical phenomenon, has prompted several destinations around the world begin to define themselves as wellness tourism destinations with their own local uniqueness. 
The word of wellness was used in a modern sense abroad at the end of 1950s (Dukes, 2016). Cited form Juhasz Gyula Faculty of Education (2006), since the first-time wellness was a mosaic word consisting of the words "well-being" and "wholeness". According to some opinions, the word was coined from the word welfare and fitness, as opposed to the word disease. The word wellness which means good health was first recorded in early 1654 (H. Dunn, 2017). If some people accept the idea that the word is used as opposed to the word disease, means a health which primarily represents lifestyle, harmony of body, mind, and spirit optimally (D. Mick \& Schwartz, 2012).

The comprehension related to body, mind, and spirit as a wellness is supported by several experts like Smith \& Kelly (2006); Modise \& Johannes (2016) who stated that wellness is generally used to mean a balance between a healthy body, mind, and spirit that results in a feeling of overall well-being. Furthermore, Myers \& Sweeney (2004) explain that wellness is a way of life oriented to optimal health and well-being. Where the body, mind, and spirit are integrated by individuals to live more fully in the human and natural community. Rickhi \& Aung (2006) also believe, creating wellness means being able to focus on practices that can benefit one or three aspects of body, mind, and spirit.

Currently, wellness is increasingly recognized as an important aspect of tourism (Voight \& Pforr, 2017). Briefly, Smith \& Puczkó (2009) explained that wellness tourism is a journey that aims to seek health and harmony in body, mind, and spirit. However, wellness tourism is a complex type of tourism. The different meanings in various countries have caused the segmentation of wellness tourist profiles to become complicated. Therefore, Smith \& Kelly (2006) also stated that the tourist wellness profile must be related to the type of product wellness, wellness activities, and wellness domains (dimension). While wellness tourist is defined as someone who can find out how to become a healthy individual, who can use their own money and free time, and take advantage of a tour package consisting of the wellness element (dimension of wellness). Wellness tourism provides various treatments or activities aimed at balancing body, mind and spirit (Smith \& Puczkó, 2009)

For years Ubud is known for its traditional and cultural richness (Prabawa $\&$ Winaja, 2018). Along with the development of wellness tourism over the world, thanks to number of authors, Ubud has now been recognized as a wellness tourism destination (Purnamawati et al., 2019). According to published data by the Central Statistics Agency BPS (2015) in Gianyar Regency, there are 74 Spa have been identified (Directory of Companies or Spa Business, 2015). Although we knew that wellness industry is not only limited to Spa (Solus Per Aqua), at least it proves that a part of wellness tourism business has grown in Ubud. Besides the Spa, Ubud is also known as a destination for yoga practice. Accoording to Citrayanthi (2015) the name of the visitor is "tamu yoga" or yoga guest, for those who are interested in spirituality, which does not necessarily have to do with Balinese culture-religious values. She also added, although there are many yoga center activities throughout Ubud, yet there is no official survey of the number of these service providers. Recently based on Destination Thailand News (2019), data for bookings made for wellness experiences regarding year-to-year growth for the wellness experience, Bali, especially Ubud, is at the top which experienced a growth of more than $7,4 \%$. 
This makes Ubud, Bali become one of the popular destinations in Asia for a wellness tourism destination (2017-2018).

Currently, the development of wellness tourism has also ignited the attention of Ministry of Health of Indonesia who also consolidate with Ministry of Tourism of Indonesia to develop international health based tourism in Indonesia (Kementerian Pariwisata, 2017). According to them, this type of tourism emphasized two types of activities namely medical tourism and wellness tourism. Medical tourism is a trip for treatment, involving medical measures, or other health checks, usually it is done by sufferers of diseases or abnormalities in health conditions with activities such as surgery, dialysis, etc. Meanwhile, wellness tourism is a trip for maintenance, recovery of physical and mental health which performed by healthy people, not suffering from an illness, or people who are recovering with activities such as spa, reflexology, fitness massage, yoga, meditation, etc.

The purpose of this article is to identify the characteristics, the activities and the dimension of wellness according to Corbin theory (2006) which states the body, mind and spirit as part of the five dimensions of wellness. This article also try to determine the phase of development by adopting the tourism area life cycle model (Butler, 1980).

\section{Wellness Tourism and its Characteristic}

\section{THEORETICAL REVIEW}

Dunn (1959) firstly, defined and published the concept of wellness which emphasizing the importance of body, mind and spirit combination. According to him, health is not about the absence of illness and stress but the presence of purpose in life, satisfaction in life, work and play, happy relationships, a healthy body, a good environment, and the presence of happiness (Dunn, 1959). Smith \& Kelly (2006) which stated that wellness is generally used to interpret the balance between body, mind, and spirit that results in a feeling of overall well-being. While wellness tourism according to Smith \& Kelly (2006) explained that wellness tourism is a type of tourism that offers a variety of activities and / or treatments to maintain, develop and improve body, mind, and spirit. Likewise Smith \& Puczkó (2009) who explained the spectrum of health tourism consists of a series of health tourism products and facilities. They classify health tourism into two namely medical tourism and wellness tourism. 
Figure 1

5 Dimensions of Wellness

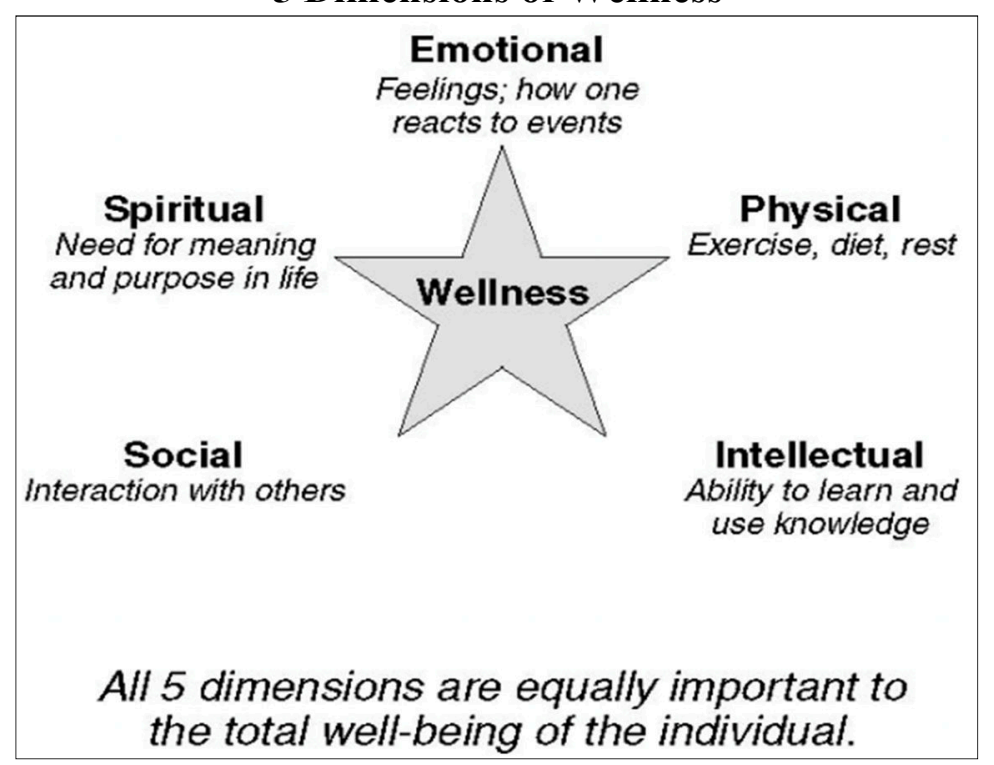

Source: Corbin et al. (2006)

\section{the total well-being of the individual.}

Based on Figure 1, Corbin et al. (2006) shows that there are five dimensions to achieving overall wellness through wellness dimensions. The five dimensions of wellness are as follows: emotional, spiritual, physical, social and intellectual. To achieve a balance of body, mind, spirit, each of these dimensions has their respective roles where it is influenced by each individual in maintaining and achieving wellness.

Figure 2

Mind, Body and Spirit: Dimension of Wellness

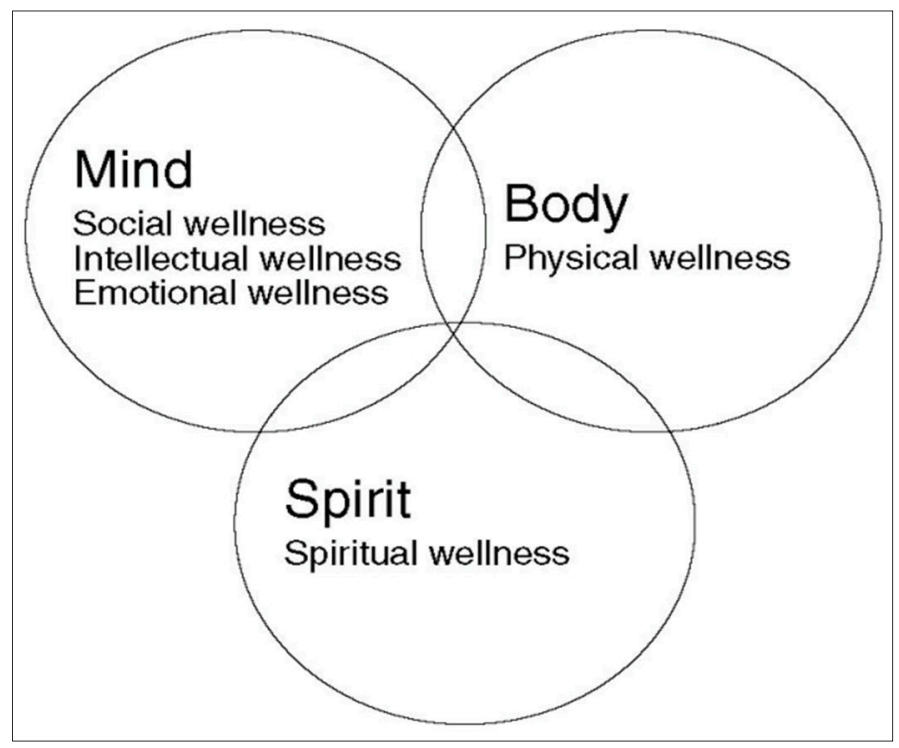

Source: Corbin et al. (2006) 
From figure 2,

1. Body (Physical Wellness): Physical wellness refers to aspects of the body that are directly related to the body. Physical wellness means when someone can go through the day with enough energy to work and play. This is the dimension that first comes to mind when people think of wellness.

2. Mind (Emotional Wellness, Social Wellness, Intellectual Wellness): Emotional wellness, social wellness, and intellectual wellness refer to aspects of mind that are associated with thoughts. Emotional wellness involves feelings of self-esteem and acceptance of different things. Emotional wellness means when someone can be open to learning new things and accepting new ideas. This openness helps someone to deal with stressful situations and accept them as part of life. Or in other words, when someone can control and express emotions in the right way. Social wellness involves interacting with others and the environment and having satisfying relationships. Social wellness means when someone has a friend with whom the person is discussing the problem and with whom the person is spending time. Intellectual wellness involves a person's ability to learn and use the knowledge that a person has acquired. Intellectual wellness means when someone is open to experience that will broaden the person's knowledge base.

3. Spirit (Spiritual Wellness): Spiritual wellness involves one's relationship with other living creatures, and the role of spiritual direction in life. Spiritual wellness means when someone works to achieve spiritual potential and find harmony in life.

Researchers note that wellness is a lifestyle choice characterized by a balance of body-mind-spirit. The balance referred to in this case is the balance of the body or physical wellness; mind or social wellness, emotional wellness, intellectual wellness; and spirit or spiritual wellness, which are the three main aspects that are important in wellness. Where each of these aspects and dimensions are interrelated with one another. Researchers note to achieve a balance of the three aspects of body, mind, spirit, each of these dimensions has a different role and it depends on how each individual prioritizes his health.

In terms of wellness traveler, Global Wellness Institute (GWI) divides wellness traveler into two types of tourists, namely; 1) Primary Wellness Traveler in this case tourists who make health (wellness) as the only destination and driving factor in choosing their trip and destination; 2) Secondary Wellness Traveler in this case tourists who strive to maintain health (wellness) during a trip, or in this case those who participate in finding health experiences when doing all kinds of travel both on vacation and business.

\section{Tourism life cycle theories from Butler}

While in analyzing the phase of development of wellness tourism in Ubud, authors also adopted Product Life Cycle by Butler (1980). According to him, a tourist area will definitely experience a life cycle of a tourist area consisting of four parts, namely (1) Discovery, (2) Local Control, (3) Institutionalism, and (4) Stagnation, Rejuvenation or Decline. The stages consist of seven stages, namely: (1) exploration, (2) involvement, (3) development, (4) consolidation, (5) stagnation), (6) decline (decrease) or (7) rejuvenation (recovery). 


\section{METHODOLOGY}

This research was conducted in August to September 2019. 8 wellness service providers were sampled purposively according to the scale of business such as spa resorts, health resorts, retreat centers, and wellness centers. Open and Closeended interviews were conducted to 8 wellness service providers. Based on literature studies and related research to wellness tourism and close-ended interviews this research will analyze the characteristic, the activities, the dimension and the phase of development. The data analysis technique used in this study is the qualitative analysis data of Miles \& Huberman (1994) with following three methods in qualitative data analysis, namely data reduction, data presentation, and drawing conclusions / verification.

\section{RESULTS AND DISCUSSION}

Based on the results of interviews conducted with informants of the wellness service providers in Ubud, it shows that currently there are 21 variant products available consisting of body, mind, or spirit treatments. For the body aspect, the highest demand treatment with the score respectively is Yoga Retreat (39), Resort Spa (33), Detox (33), Health Resort (19), Wellness Centre (17), Ayur Vedic (15). On the other hands, for mind treatments, the highest number of score are Music Therapy (29), Stress Release (23), Emotional Detox (19). While, for the spirit treatment, the highest score are Meditation and Spriritual Retreat with score 38 and 37 respectively.

Table 1

Characteristics of Wellness Products

\begin{tabular}{|c|c|c|c|c|c|c|c|c|}
\hline No & Wellness Product & Availability & $\begin{array}{c}\text { Very } \\
\text { Interested } \\
(5) \\
\end{array}$ & $\begin{array}{c}\text { Interested } \\
(4) \\
\end{array}$ & $\begin{array}{c}\text { Moderate } \\
\text { (3) } \\
\end{array}$ & $\begin{array}{c}\text { Not } \\
\text { Interested } \\
(2) \\
\end{array}$ & $\begin{array}{c}\text { Very Not } \\
\text { Interested } \\
(1) \\
\end{array}$ & Total \\
\hline \multicolumn{9}{|c|}{ Body } \\
\hline 1 & Day Spa & $\checkmark$ & - & - & 3 & - & - & 9 \\
\hline 2 & Hotel Spa & $\checkmark$ & - & - & 1 & - & - & 3 \\
\hline 3 & Resort Spa & $\checkmark$ & 5 & 2 & - & - & - & 33 \\
\hline 4 & Eco-Spa & $\checkmark$ & 1 & - & - & - & - & 5 \\
\hline 5 & Ashrams & $\checkmark$ & 2 & - & - & - & - & 10 \\
\hline 6 & Yoga Retreat & $\checkmark$ & 7 & 1 & - & - & - & 39 \\
\hline 7 & $\begin{array}{l}\text { Thalassotherapy } \\
\text { Spa }\end{array}$ & $x$ & - & - & - & - & - & 0 \\
\hline 8 & Thermal Baths & $\checkmark$ & - & - & 1 & - & - & 3 \\
\hline 9 & Health Resort & $\checkmark$ & 3 & 1 & - & - & - & 19 \\
\hline 10 & Wellness Center & $\checkmark$ & 1 & 3 & - & - & - & 17 \\
\hline 11 & Wellness Cruise & $x$ & - & - & - & - & - & 0 \\
\hline 12 & Healthy Hotel & $\checkmark$ & 1 & 1 & - & - & - & 9 \\
\hline 13 & Beauty Salon & $\checkmark$ & 1 & - & 2 & - & - & 11 \\
\hline 14 & $\begin{array}{l}\text { Gym/Fitness } \\
\text { Center }\end{array}$ & $\checkmark$ & - & 1 & 2 & - & - & 10 \\
\hline 15 & Holistic Care & $\checkmark$ & 1 & - & - & - & - & 5 \\
\hline 16 & Detox & $\checkmark$ & 5 & 2 & - & - & - & 33 \\
\hline 17 & Ayurveda & $\checkmark$ & 3 & - & - & - & - & 15 \\
\hline \multicolumn{9}{|c|}{ Mind } \\
\hline 18 & Music Therapy & $\checkmark$ & 5 & 1 & - & - & - & 29 \\
\hline
\end{tabular}




\begin{tabular}{|c|l|c|c|c|c|c|c|c|}
\hline 19 & Emotional Detox & $\checkmark$ & 3 & 1 & - & - & - & 19 \\
\hline 20 & Stress Release & $\checkmark$ & 3 & 2 & - & - & - & 23 \\
\hline 21 & Painting Therapy & $\checkmark$ & - & 1 & - & - & - & 4 \\
\hline \multicolumn{2}{|c|}{ Spirit } & & & & & & & \\
\hline 22 & Meditation Retreat & $\checkmark$ & 6 & 2 & - & - & - & 38 \\
\hline 23 & Spiritual Retreat & & 5 & 3 & - & - & - & 37 \\
\hline
\end{tabular}

Source: Interviews and check list with informants (2019)

From the results of interviews conducted with informants, it can be seen that each provider has a different model of activity or uniqueness between sait and others. From the table bellow, it can be seen that wellness activities in Ubud were considered more relevant to the daily lifestyle of the Balinese culture, especially the spirit, customs, tradition of Balinese-Hinduism. Moreover, the local valuable knowledge of traditional Balinese herbs is also offered to provide a quality wellness experience.

Table 2

The Wellness Activities in Ubud

\begin{tabular}{|c|c|c|}
\hline No & $\begin{array}{l}\text { Wellness } \\
\text { Service } \\
\text { Provider }\end{array}$ & Wellness Activities \\
\hline 1 & $\begin{array}{l}\text { Adiwana Resort } \\
\text { Jembawan }\end{array}$ & $\begin{array}{l}\text { Offering Making Canang Sari, Cooking Class, Purnama Balinese Full } \\
\text { Moon Celebration, Heavenly High Tea. }\end{array}$ \\
\hline 2 & $\begin{array}{lr}\text { Bagus } & \text { Jati } \\
\text { Health } & \text { and } \\
\text { Wellbeing } & \\
\text { Retreat } & \end{array}$ & $\begin{array}{l}\text { Nature Walk, Aqua Aerobic, Traditional "Jamu", Medicines } \\
\text { Demonstration, Making Canang Sari, Spa Recipe (Making Natural } \\
\text { Treatment Product), Balinese Dance Lesson, Balinese Cooking Class, } \\
\text { Trekking, Village Cycling, Village Tour, Holy Spring Temple Tour, } \\
\text { Balinese Purification, Ritual "Melukat" and Blessing Sebatu, Balinese } \\
\text { Massage Lesson. }\end{array}$ \\
\hline 3 & $\begin{array}{l}\text { Fivelements } \\
\text { Retreat }\end{array}$ & $\begin{array}{l}\text { Healing with Planted-based Cuisine, Detox with Planted-based Cuisine, } \\
\text { Culinary Trainings, The Dinner Club, Exclusive Day Experience, } \\
\text { Group Day Experience, Romantic Day Experience. }\end{array}$ \\
\hline 4 & $\begin{array}{l}\text { Gaia Retreat } \\
\text { Center }\end{array}$ & $\begin{array}{l}\text { Balinese Dance *Evening* Show by the Lotus, Pond Saraswati Temple } \\
\text { at Kecak Fire and Trance Dance Evening Show, Tirta Empul Holy } \\
\text { Water Spring Cleanse, Historic Temples \& Meditation Chambers of } \\
\text { Gunung Kawi, Sacred Monkey Florest, Tegunungan Waterfall, Canang } \\
\text { Sari Flower, Offering Workshop, Holy Water Blessings Floral } \\
\text { Purification, Sunrise or Sunset Bali Rice Fields Walk, Mala Beads } \\
\text { Making Workshop. }\end{array}$ \\
\hline 5 & $\begin{array}{l}\text { Mansion } \\
\text { Wellness } \\
\text { Center }\end{array}$ & $\begin{array}{l}\text { Host Your Retreat or Event, State of the Art Wellness, Retreats, } \\
\text { Workshop, Daily Yoga Class (Lynger,Acro,Fly,Yin,Yoga,etc) Weekly } \\
\text { Events, Weekly Meditations (Include Reiki), Teacher Training. }\end{array}$ \\
\hline 6 & $\begin{array}{l}\text { Maya Ubud } \\
\text { Resort and Spa }\end{array}$ & $\begin{array}{l}\text { Cooking Adventure in Maya's Spice Garden, Cycling Tour Ubud } \\
\text { Cycling, Trekking Village Rice Paddy Walk. }\end{array}$ \\
\hline 7 & $\begin{array}{l}\text { Natural Instinct } \\
\text { Healing }\end{array}$ & $\begin{array}{l}\text { Beauty Workshop, Health Workshop, Naturopathic \& Nutritional, } \\
\text { Personal Mentoring, Flower Essence Therapy. }\end{array}$ \\
\hline 8 & $\begin{array}{l}\text { Ubud Sari } \\
\text { Health Resort }\end{array}$ & $\begin{array}{l}\text { Adventure Sport, Sunrise Walk Herb Learning Walk, Rice Paddy Walk, } \\
\text { Explore Ubud. }\end{array}$ \\
\hline
\end{tabular}

Source: Interviews and check list with informants (2019) 


\section{The Interrelation Between Characteristic, Activities and Dimension of Wellness di Ubud}

Based on Table 4 bellow, it can be explained that the characteristic of wellness products that are in demand in Ubud are yoga retreats, meditation retreats, spiritual retreats, detoxes, and spa resorts. Table 4 shows that wellness products in Ubud are dominated by retreats. Yoga retreats, meditation retreats, and spiritual retreats are retreats that have become a form of wellness product program in Ubud that are in demand besides detox and spa resorts.

Most of these demands are attracted with a desire to ask a fully packaged service that can meet the aspects and dimensions of the wellness, in this case how to get some practices combination of body, mind and spirit.

Table 3

Wellness Product, Wellness Activities in Ubud

\begin{tabular}{|c|c|c|}
\hline $\begin{array}{l}\text { Characteristic of } \\
\text { Wellness Product }\end{array}$ & Typical Activities & Wellness Dimension) \\
\hline Yoga Retreat & $\begin{array}{l}\text { Nature Walk, Trekking, Aqua Aerobic, } \\
\text { Village Cycling, Village Tour, Cycling } \\
\text { Tour Ubud Cycling, Trekking Village } \\
\text { Rice Paddy Walk, Adventure Sport, } \\
\text { Sunrise Walk, Rice Paddy Walk, } \\
\text { Explore Ubud, State of the Art } \\
\text { Wellness, Retreats, Daily Yoga Class } \\
\text { (Lynger, Acro, Fly, Yin Yoga, etc). }\end{array}$ & $\begin{array}{l}\text { Body (physical wellness) } \\
\text { Mind (Social, intellectual \& } \\
\text { emotional wellness) } \\
\text { Spirit (Spiritual wellness) }\end{array}$ \\
\hline Meditation Retreat & $\begin{array}{l}\text { Weekly Meditation, Tirta Empul Holy } \\
\text { Water Spring Cleanse, Historic } \\
\text { Temples \& Meditation Chambers of } \\
\text { Gunung Kawi, Sacred Monkey Florest, } \\
\text { Holy Water Blessings Floral } \\
\text { Purification, Sunrise or Sunset Bali } \\
\text { Rice Fields Walk, Flower Essence } \\
\text { Therapy. }\end{array}$ & $\begin{array}{l}\text { Body (physical wellness) } \\
\text { Mind (Social, intellectual \& } \\
\text { emotional wellness) } \\
\text { Spirit (Spiritual wellness) }\end{array}$ \\
\hline Spiritual Retreat & $\begin{array}{l}\text { Offering Making Canang Sari, Making } \\
\text { Canang Sari, Balinese Dance Lesson, } \\
\text { Holy Spring Temple Tour, Balinese } \\
\text { Purification, Ritual "Melukat" and } \\
\text { Blessing Sebatu, Canang Sari Flower, } \\
\text { *Evening* Show by the Lotus, Pond } \\
\text { Saraswati Temple at Kecak Fire and } \\
\text { Trance Dance Evening Show, Purnama } \\
\text { Balinese Full Moon Celebration, } \\
\text { Balinese Dance. }\end{array}$ & $\begin{array}{l}\text { Body (physical wellness) } \\
\text { Mind (Social, intellectual \& } \\
\text { emotional wellness) } \\
\text { Spirit (Spiritual wellness) }\end{array}$ \\
\hline Detox & $\begin{array}{l}\text { Heavenly High Tea, Healing with } \\
\text { Planted-based Cuisine, Detox with } \\
\text { Planted- based Cuisine, Culinary } \\
\text { Trainings, Mala Beads Making } \\
\text { Workshop, Cooking Adventure in }\end{array}$ & $\begin{array}{l}\text { Body (physical wellness) } \\
\text { Mind (Social, intellectual \& } \\
\text { emotional wellness) } \\
\text { Spirit (Spiritual wellness) }\end{array}$ \\
\hline
\end{tabular}




\begin{tabular}{|l|l|l|}
\hline & $\begin{array}{l}\text { Maya's Spice Gardening, Beauty } \\
\text { Workshop, Health Workshop, } \\
\text { Naturopathic \& Nutritional, Personal } \\
\text { Mentoring, Teacher Training. }\end{array}$ & \\
\hline Resort Spa & $\begin{array}{l}\text { Cooking Class, Traditional "Jamu", } \\
\text { Balinese Cooking Class, Medicines }\end{array}$ & $\begin{array}{l}\text { Body (physical wellness) } \\
\text { Mind (Social, intellectual \& } \\
\end{array}$ \\
& $\begin{array}{l}\text { Demonstration, Spa Recipe (Making } \\
\text { emotional wellness) }\end{array}$ & Satural Treatment Product), Balinese \\
& Spirit (Spiritual wellness) \\
& Traditional "Jamu". & \\
\hline
\end{tabular}

Source: Interviews and check list with informants (2019)

\section{Body-Mind-Spirit Wellness Tourism di Ubud}

Based on the results of data analysis from this study, it can be concluded that the definition of wellness which is defined as the balance of body, mind, and spirit has now been fully implemented in Ubud, which is explained in Figure 4 below.

Figure 3

Dimension of Wellness di Ubud

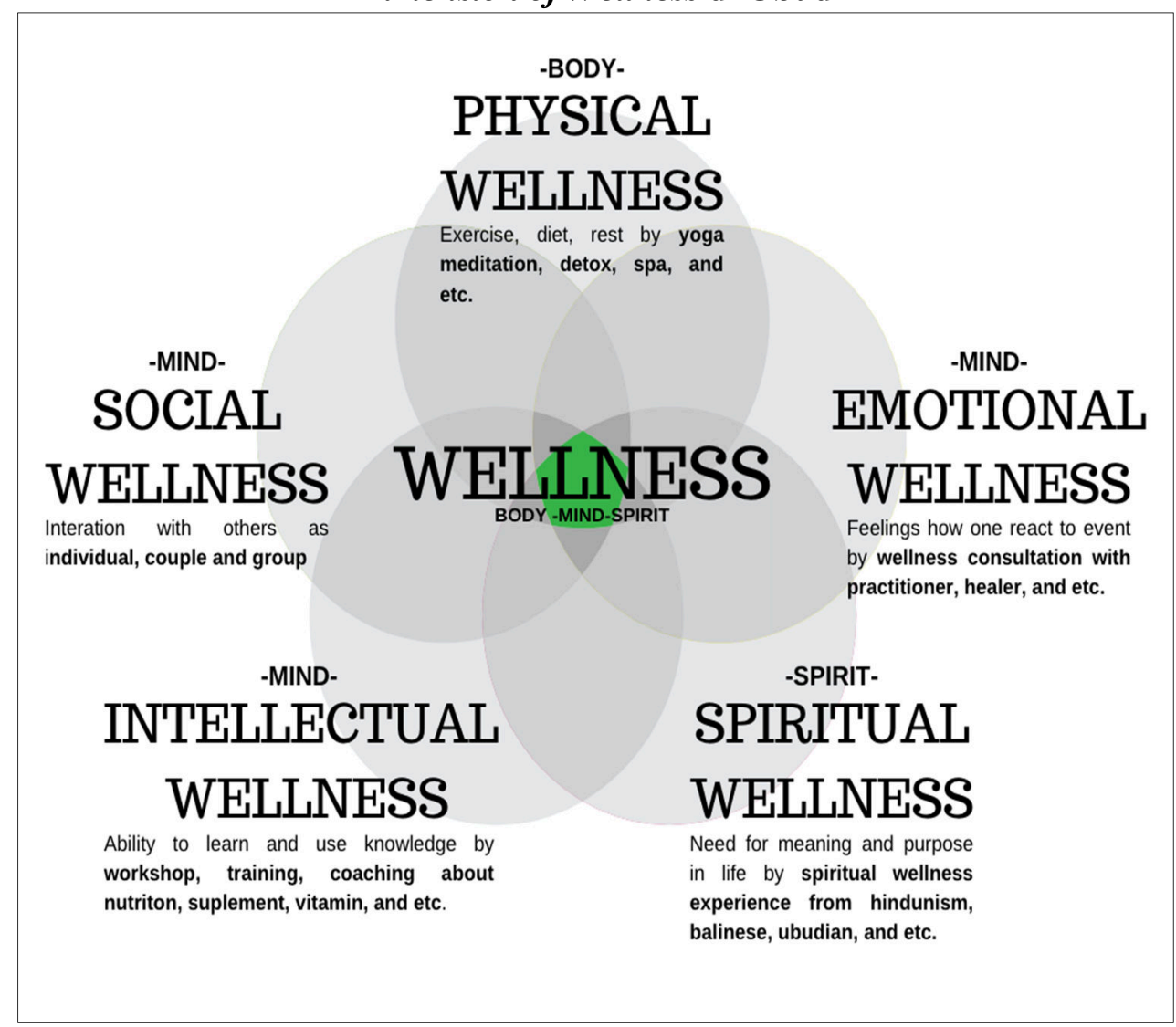

Source: Synthesis of information from informant (2019)

Based on Figure 4 above, it can be seen that Ubud has fulfilled the five dimensions of wellness determined by Corbin (2006), which states that there are five main dimensions of wellness, namely physical wellness, emotional wellness, social wellness, intellectual wellness, and spiritual wellness for achieve balance of 
body, mind, and spirit. Overall, the wellness in Ubud has fully fulfilled the aspect of body, mind and spirit in which the three aspects are reflected in the five applications of the current dimensions of wellness. The aspects of body, mind, and spirit are very important in interpreting wellness as a whole. The aspects of body, mind, and spirit determine the success of the wellness itself. Broadly speaking, the wellness service provider has implemented three aspects and the five dimensions (dimensions of wellness) in which each dimension is applied in different ways.

\section{The Life Cycle of Wellness Tourism in Ubud}

To determine the development phase of wellness tourism in Ubud, open interviews were also conducted with 8 informants to find out the history of the development of wellness tourism in Ubud. The narrative description of the informants will then be matched with the indications explained in Butler's theory at each phase.

\section{Table 4}

Life Cycle of Wellness Tourism di Ubud

\begin{tabular}{|c|c|c|c|}
\hline Years & Informant & Description & Phase \\
\hline $\begin{array}{l}1990- \\
1995\end{array}$ & $\begin{array}{l}\text { Interview with Ketut } \\
\text { Nick Darsana, on } 22 \\
\text { June } 2019\end{array}$ & $\begin{array}{l}\text { "The influx of wellness industry } \\
\text { Bali was started with the } \\
\text { establishment of a SPA in Bali, } \\
\text { the familiarization of wellness } \\
\text { began to exist here around the } \\
\text { year } 1995 \text { but with different } \\
\text { words like as relaxation, } \\
\text { refreshment, and rejuvenate not } \\
\text { specifically with the terms } \\
\text { "wellness". " }\end{array}$ & $\begin{array}{l}\text { The first } \\
\text { phase. } \\
\text { Exploration/ } \\
\text { discovery is } \\
\text { characterized } \\
\text { by the concept } \\
\text { of wellness } \\
\text { tourism that } \\
\text { began to exist } \\
\text { and be } \\
\text { explored. }\end{array}$ \\
\hline 2000 & $\begin{array}{l}\text { Interview with I } \\
\text { Wayan Yogi Raditya, } \\
\text { on 20 June } 2019\end{array}$ & $\begin{array}{l}\text { "The growth of Ubud's wellness } \\
\text { service provider began to } \\
\text { increase in } 2000 \text { but it was } \\
\text { managed traditionally." }\end{array}$ & \multirow{5}{*}{$\begin{array}{l}\text { The second } \\
\text { phase. } \\
\text { Involvement } \\
\text { (participation) } \\
\text {, is marked by } \\
\text { the growth } \\
\text { number of } \\
\text { local wellness } \\
\text { service } \\
\text { providers and } \\
\text { the tourist } \\
\text { recognition of } \\
\text { Balinese } \\
\text { traditional } \\
\text { healer }\end{array}$} \\
\hline \multirow{2}{*}{2002} & $\begin{array}{l}\text { Interview with I } \\
\text { Wayan Yogi Raditya, } \\
\text { on 20 June } 2019\end{array}$ & $\begin{array}{l}\text { "In } 2002 \text { the phenomenon of } \\
\text { yoga treatment increased in } \\
\text { numbers, especially in Ubud }\end{array}$ & \\
\hline & $\begin{array}{l}\text { Interview with Ketut } \\
\text { Nick Darsana, on } 22 \\
\text { June } 2019\end{array}$ & $\begin{array}{l}\text { "Wellness tourism in Ubud } \\
\text { began to be offered as a } \\
\text { complete package in } 2002\end{array}$ & \\
\hline \multirow[b]{2}{*}{2006} & $\begin{array}{l}\text { Interview with I } \\
\text { Wayan Yogi Raditya, } \\
\text { on 20 June } 2019\end{array}$ & $\begin{array}{l}\text { "The book Eat, Pray, Love from } \\
\text { Elizabeth Gillbert influenced } \\
\text { the image of wellness tourism } \\
\text { in Ubud." (2006) }\end{array}$ & \\
\hline & $\begin{array}{l}\text { Interview with Devi } \\
\text { Putrining Larasati, on } \\
\text { 19 June } 2019\end{array}$ & $\begin{array}{l}\text { "The book Eat, Pray, Love by } \\
\text { Elizabeth Gilbert promotes } \\
\text { traditional healer "Balian" Bali } \\
\text { widely especially in Ubud, } \\
\text { Gianyar." (2006) }\end{array}$ & \\
\hline
\end{tabular}




\begin{tabular}{|c|c|c|c|}
\hline & $\begin{array}{l}\text { Interview with I } \\
\text { Wayan Yogi Raditya, } \\
\text { on 20 June } 2019\end{array}$ & $\begin{array}{l}\text { "Some vegetarian restaurants } \\
\text { have started to appear." (2007) }\end{array}$ & \multirow{7}{*}{$\begin{array}{l}\text { The third } \\
\text { phase. } \\
\text { Development } \\
\text {, marked by } \\
\text { the start of the } \\
\text { promotion } \\
\text { (Bali Spirit } \\
\text { Festival and } \\
\text { Hollywood } \\
\text { movie } \\
\text { entitled Eat, } \\
\text { Pray and } \\
\text { Love). } \\
\text { Moreover, in } \\
\text { this phase, the } \\
\text { government } \\
\text { has also } \\
\text { joined and } \\
\text { involved with } \\
\text { stakeholders } \\
\text { in developing } \\
\text { this industry } \\
\text { (The wellness } \\
\text { service } \\
\text { provider in } \\
\text { various scale, } \\
\text { restaurants } \\
\text { and Ministry } \\
\text { of Tourism } \\
\text { and the } \\
\text { Ministry of } \\
\text { Health) }\end{array}$} \\
\hline $\begin{array}{l}2007- \\
2009\end{array}$ & $\begin{array}{l}\text { Interview with Devi } \\
\text { Putrining Larasati, on } \\
\text { 19 June } 2019\end{array}$ & $\begin{array}{l}\text { "Bali Spirit Festival (2008) } \\
\text { further strengthens the position } \\
\text { of Ubud, Bali as a wellness } \\
\text { tourism destination. Until } \\
\text { (2009) a vegan restaurant } \\
\text { appeared." }\end{array}$ & \\
\hline \multirow{3}{*}{$\begin{array}{l}2010- \\
2017\end{array}$} & \multirow[b]{2}{*}{$\begin{array}{l}\text { Interview with Devi } \\
\text { Putrining Larasati, on } \\
\text { 19 June } 2019\end{array}$} & $\begin{array}{l}\text { The Film of Eat, Pray, Love } \\
\text { makes Ubud tourism area better } \\
\text { known as the center of wellness } \\
\text { in Bali. (2010) }\end{array}$ & \\
\hline & & $\begin{array}{l}\text { "Retreat centers were starting to } \\
\text { improve (yoga retreats, } \\
\text { meditation retreats, spiritual } \\
\text { retreats) in Ubud in a } \\
\text { professional management." } \\
(2010)\end{array}$ & \\
\hline & $\begin{array}{l}\text { Interview with Kadek } \\
\text { Adnyani Larasati, on } \\
\text { July 17, } 2019\end{array}$ & $\begin{array}{l}\text { "Some resorts in Ubud have } \\
\text { begun to define themselves as } \\
\text { wellness resorts." (2011) }\end{array}$ & \\
\hline \multirow[t]{2}{*}{$\begin{array}{l}2017- \\
\text { Now }\end{array}$} & $\begin{array}{l}\text { Interview with } \\
\text { Thomas Bagus, on } \\
\text { July 2, } 2019\end{array}$ & $\begin{array}{l}\text { "Wellness centers start to be } \\
\text { exist in Ubud (wellness centers, } \\
\text { health resorts, wellness resorts) } \\
\text { and offer wellness in one } \\
\text { complete package (retreat } \\
\text { program: treatment, meal, } \\
\text { accommodation, excursion, } \\
\text { etc.)." (2017) } \\
\text { "The growing trend of healthy } \\
\text { lifestyles open the diversity of } \\
\text { restaurants that offer more eco- } \\
\text { friendly food such as gluten } \\
\text { free, raw, plant-based, ranging } \\
\text { from simple "warung" eating } \\
\text { place to fine dining restaurant in } \\
\text { Ubud (2017)." }\end{array}$ & \\
\hline & $\begin{array}{l}\text { Interview with Ni } \\
\text { Made Suarini, on July } \\
\text { 2, } 2019\end{array}$ & $\begin{array}{l}\text { "The Ministry of Tourism and } \\
\text { the Ministry of Health signed a } \\
\text { Memorandum of Understanding } \\
\text { on the Development of Health } \\
\text { and Wellness Tourism." }\end{array}$ & \\
\hline
\end{tabular}

Source: Synthesis of information from informant (2019)

As for the outline, the description of the development of wellness tourism in Ubud can be seen in Figure 3 below. 
Figure 4

\section{Wellness Tourism Phase in Ubud}

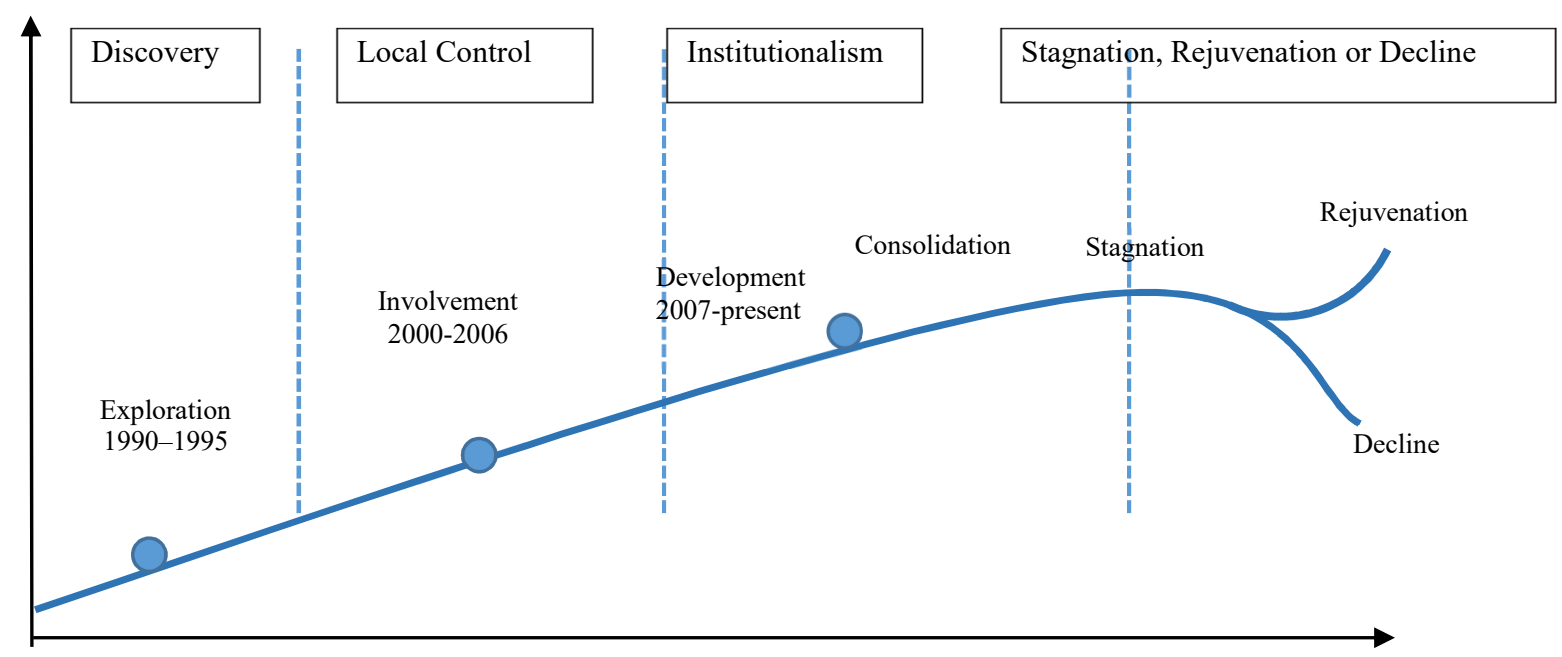

Source: Synthesis of information from informant (2019) based on Butler theory

\section{Exploration (1990-1995s)}

The emergence of wellness tourism industry in Ubud begins with the development of Spa in Bali. Since the end of 1990s this industry has developed rapidly and brought the initial concept of wellness tourism modernly in the island include Ubud. It can be remarked that the terms of wellness has existed since 1995s in Ubud where there were many Spa started offering various types of treatments. However the terms of wellness was not defined specifically at that era, the Spa product has introduced the existence of wellness tourism in Ubud.

\section{Involvement (2000-2006s)}

Wellness product increased significantly in 2000s. At that time wellness businesses service providers with various type were are mushrooming throughout Ubud. Despite the large number of service providers were existed, however they were still managed traditionally. Since the demand has increased, then wellness tourism in Ubud began to develop in 2002 and was offered in complete package from accommodation, retreat to excursion. In terms of recognition, in 2006s especially after the circulation of the book Eat, Pray, Love, the growth of wellness became very rapid. This book affects the development of wellness tourism in Ubud and also promotes the existence of Balinese Traditional Healer or also known as "Balian Bali". These phenomenon is considered as the second phase of cycle, which can be marked by the participation of Balian Balinese (Balinese Traditional Healer) and wellness service providers on a local scale.

\section{Development (2007-present)}

By the growth of various wellness providers in Ubud which began from the previous year, the wellness service providers are managed more attractive, commercial and professional. These can be remarked by the growth numbers of various types and business scale of wellness providers (not limited to Spa) such as retreat center, wellness center, wellness resort, and health resort. In 2008, the Bali 
Spirit Festival also strengthened the position of Ubud, Bali as a wellness tourism destination. Since then, vegan, vegetarian, eco food, and gluten free restaurants have begun to emerge. Furthermore, the Eat, Pray, Love movie which was adapted from the novel with the same title making the Ubud increasingly known as a wellness center in Bali.

In line with its development, in 2017 the Ministry of Tourism and the Ministry of Health of Indonesia have agreed on a Memorandum of Understanding on the Development of Health Tourism with two main focuses, namely medical tourism and wellness tourism (2017). The Ministry of Tourism and the Ministry of Health's agreement covers the coordination and harmonization of policies and programs in the development of health tourism, quality improvement, promotion development, community empowerment, data exchange and information, integrated monitoring and evaluation related to the development of health tourism.

Based on the Memorandum of Understanding, it can be assessed that the development of wellness tourism is starting to become a concern of stakeholders because it is considered in accordance with the government's target in terms of bringing quality tourists. This can be seen from the length of stay of tourists and how much tourists spend.

\section{CONCLUSION}

The aspects of body, mind, and spirit are the three main aspects that are most appropriate for use in describing the meaning of wellness as a whole. To maintain or achieve optimal wellness requires a balance of body, mind, and spirit and fulfill the dimensions within. Wellness consists of several dimensions that are interrelated and influence each other. There are five dimensions of wellness, namely body, or physical wellness; mind, or emotional wellness, social wellness, and intellectual wellness; and spirit, or spiritual wellness.

The characteristics of wellness products in Ubud currently are considered more diverse. The diversity of wellness products referred to in this case is reflected in the wellness products that are in great demand in Ubud, namely yoga retreats, meditation retreats, spiritual retreats, detoxes, and spa resorts. Yoga retreat, meditation retreat, spiritual retreat are wellness products that are in great demand and have fulfilled all three aspects of wellness namely body, mind, and spirit. While detox and resort spas are wellness products that meet both aspects of wellness, body and mind. The characteristics of wellness activities in Ubud are considered more relevant to the daily life, customes, tradition of the Balinese-Hindusim. Beside that, wellness experience offered in Ubud is also enriched with the local knowledge of traditional Balinese herbs. Therefore, it can be concluded that the wellness tourism in Ubud now, has fulfilled the dimensions in wellness.

While in the terms of development phase, currently Ubud can still be said to be staying in the development phase. Although the development of wellness tourism began a long time ago, the results of interviews conducted and literature research indicate that the demand for wellness tourism as an alternative tourism is still quite high. In addition, the diverse variety of activities offered also makes the atmosphere of wellness tourism in Ubud still competitive between the service providers and the forms of activity. 


\section{REFERENCES}

BPS. (2015). Direktori Perusahaan atau Usaha SPA. Badan Pusat Statistik.

Butler, R. W. (1980). The concept of a tourist area cycle of evolution: implications for management of resources. Canadian Geographer/Le Géographe Canadien, 24(1), 5-12.

Citrayanthi, N. M. (2015). Ubud is calling me: Yoga tourism and development in vibrant ubud, Bali. University of Leiden, Leiden, Netherlands.

Corbin, C. B., Lindsey, R., Welk, G., \& Corbin, W. R. (2006). Concepts of fitness and wellness: A comprehensive lifestyle approach. McGraw-Hill Boston.

Destination Thailand News. (2019). Thailand and Bali are Top Destinations in Asia for Wellness Travel. https://destinationthailandnews.com/lifestylenews/health-and-wellness/thailand-and-bali-are-top-dest

Dukes, H. (2016). Cultural Effects On Wellness As It Applies ToSociety And The Individual: An International Comparison Of Germany And The United States Of America. Scholars Work Grand Valley State University. https://scholarworks.gvsu.edu/cgi/viewcontent.cgi?article=1494\&context= honorsprojects

Dunn, H. (2017). Hal and Me (And Don and Bill), or How we got wellness on the map, and how hal's vision has been overlooked/ignored/bypassed/wattered down. Wellness Award, 42nd Annual National Wellness Conference.

Dunn, H. L. (1959). High-level wellness for man and society. American Journal of Public Health and the Nations Health, 49(6), 786-792.

Juhasz Gyula Faculty of Education. (2006). Juhasz Gyula Faculty of Education.

Kementerian Pariwisata. (2017). Nota Kesepahaman Antara Kementerian Kesehatan Dan Kementerian Pariwisata. https://www.kemenpar.go.id/post/nota-kesepahaman-antara-kementeriankesehatan-dan-kementerian-pariwisata

Mick, D., \& Schwartz, B. (2012). Can consumers be wise? Aristotle speaks to the 21st century. In D. G. Mick, S. Pettigrew, C. Ozanne, \& P. \& J. L. (Eds.), Transformative Consumer Research for Personal and Collective WellBeing. Routledge.

Miles, M. B., \& Huberman, A. M. (1994). Qualitative data analysis: An expanded sourcebook. sage.

Modise, L., \& Johannes, M. L. (2016). Well-Being and Wellness in the TwentyFirst Century: A Theanthropocosmic Approach. Journal of Religion and Health, 55(6), 1876-1890.

Myers, J. E., \& Sweeney, T. J. (2004). Wellness in counseling: An overview. Professional Counseling Digest, 1, 1-2.

Prabawa, I. W. S. W., \& Winaja, I. W. (2018). Balinese Art and Tourism Promotion: From the 1931 'Paris Colonial Exposition'to the Contemporary 'Paris Tropical Carnival.' Jurnal Kajian Bali (Journal of Bali Studies), 8(1), 1734.

Purnamawati, O., Putra, N. D., \& Wiranatha, A. S. (2019). Medical Tourism in Bali: A Critical Assessment on the Potential and Strategy for its Development. Journal of Travel, Tourism and Recreation, 1(2), 39-44.

Rickhi, B., \& Aung, S. (2006). Wellness is state of mind, body and spirit. Complementary and Alternative Health Affiliate of the Canadian Health 
Network.

Smith, M, \& Puczkó, L. (2009). Health and wellness tourism Oxford. ButterworthHeinemann Elsevier.

Smith, Melanie, \& Kelly, C. (2006). Wellness tourism. Tourism Recreation Research, 31(1), 1-4.

Voight, C., \& Pforr, C. (2017). Wellness Tourism. Routledge Advances in Tourism. Youngman, I. (2018). Wellness Tourism is Worth US\$ 639 BN, But What do These Figures Include? International Medical Travel Journal. https://www.imtj.com/news/wellness-tourism-worth-us639bn/\%0A 